\title{
Technology Based Self Service Banking Service Quality Evaluation: a Graph Theoretic Approach
}

\author{
Rajiv Sindwani ${ }^{1}$ and Dr Manisha Goel ${ }^{2}$ \\ ${ }^{1}$ Assistant Professor, ${ }^{2}$ Associate Professor, \\ YMCA University of Science \& Technology, Faridabad, India \\ ${ }^{1}$ rajiv_sindwani@yahoo.co.in, ${ }^{2}$ singla_manisha@rediffmail.com
}

\begin{abstract}
The technology based self service banking (TBSSB) refers to automated banking services that customer avail in self service mode using various electronic banking channels, without any interaction with bank employees. Researchers have used numerous methods to evaluate automated banking service quality. In this paper, a methodology to quantify the overall effect of key TBSSB service quality attributes is discussed. The TBSSB service quality index is calculated by using fuzzy along with graph theory and matrix methods. Broad attributes affecting TBSSB service quality are identified. The fuzzy numbers are used to convert intangible attributes to crisp scores and then graph theoretic approach has been applied to calculate the single numerical index. This study may help bank management to take various decisions pertaining to TBSSB service quality using TBSSB index. It will also assist academicians in better understanding of TBSSB services.
\end{abstract}

Keywords: Technology based self service banking, Fuzzy Numbers, Graph Theoretic Approach, TBSSB index

\section{Introduction}

Branch banking is progressively being replaced by the technology based self service banking (TBSSB) or self service automated banking. The TBSSB services are provided by banks with the help of automated channels like ATM, internet banking, mobile banking and tele banking. Across the world, the banks are using technology for providing services in the self service mode through the various electronic channels. This trend is prevalent in India also. The services through these channels offer numerous advantages both to the banks and their customers. For the banks, the benefits are reduction in transaction expenses and lesser load on branches. For the clients, self administration provides value to customers by anytime and anywhere banking. The acceptance of automated banking among people is growing day by day. This growth leads to growing interest of organizations and academicians in measuring automated banking service quality. Most of the studies on automated banking quality cover only one of the automated banking channels. As explained by Joshua [1], customers tend to use the services of the different automated banking channels in a complimentary manner. So, considering aspects pertaining to only one channel will not be able to present the comprehensive picture of automated banking service quality. Banks need to spend huge amount of money for providing TBSSB services. So there must be an evaluation method that can help banks to quantify TBSSB service quality in single numeric value. Therefore, in the present study we find broad attributes affecting automated selfservice banking service quality. On the basis of various attributes affecting TBSSB service quality, single numerical index value (TBSSB index) for automated banking using Fuzzy numbers and Graph Theoretic Approach (GTA) is calculated. Maximum and minimum value of TBSSB index is also calculated. 


\section{Literature Review}

In the past, studies were conducted to evaluate automated banking service quality by using numerous methods. Most of the evaluation methods emphasized on grouping of various attributes affecting automated banking service quality into dimensions (factors) using factor analysis. Some studies also used approaches like Analytical Hierarchy Process (AHP), Preference Ranking Organization Method for Enrichment Evaluation (PROMETHEE), Elimination and Choice Expressing Reality (ELECTRE), Fuzzy TOPSIS etc for evaluating automated banking service quality.

Joseph et al., [2] investigated the impact of the technology enabled service delivery on perceived service quality in Australian banking. The researchers identified the six dimensions of e-banking service quality as: convenience/accuracy; feedback/complaint management; efficiency; queue management; accessibility and customisation using the items generated from focus groups. Broderick \& Vachirapornpuk [3] identified five key elements that are regarded as central influences on perceived service quality. The elements are customer expectations of the service, the image and reputation of the service organization, aspects of the service setting, the actual service encounter, and customer participation. Al-Hawari et al., [4] proposed 22-item instrument to capture key characteristics of Banks' Automated Service Quality from the customers' perspective. The instrument was designed to measure five dimensions of service quality which included ATM quality, telephone banking quality, Internet banking quality, customer perception of core service and customer perception of price. Ibrahim et al., [5] explored six key factors of the electronic service quality perceptions of UK banking customers. The factors include the provision of convenient/accurate electronic banking operations; the accessibility and reliability of service provision; good queue management; service personalisation; the provision of friendly and responsive customer service; and the provision of targeted customer service. Rasolinezhad [6] ranked five electronic banking methods comprising ATM banking, Phone banking, Internet banking, Mobile banking and SMS banking in Iran using Analytic Hierarchy Process (AHP). Amiri et al., [7] investigated and explained effective factors for improving e-banking by using Fuzzy TOPSIS in Persian bank. Ganguli and Roy [8] conducted a research on undergraduate students of a University in the Massachusetts state of the USA. They identified four generic service quality dimensions in the technology-based banking services - customer service, technology security and information quality, technology convenience, and technology usage easiness and reliability. Kahraman \& Kaya [9] proposed an e-banking website quality assessment methodology based on an integrated fuzzy AHP-ELECTRE approach to rank the alternatives. Fuzzy AHP was used to assign weight to criterion and fuzzy ELECTRE was used to assess the quality levels of the websites. Elbadrawy et al., [10] developed a hybrid model evaluation of e-banking services. By using PROMETHEE in conjunction with AHP, they proposed a structured model for evaluating the performance of the three electronic banking services; ATMs, Telephone Banking, and Internet Banking. AHP was used to determine the relative importance of service quality multi-criteria dimensions from bank customers' point of view, and PROMETHEE method was applied for ranking the performance of different electronic banking services.

From the literature survey, it is observed that there is hardly any literature on mathematical modelling of automated banking service quality using Fuzzy numbers and Graph Theoretic Approach resulting in single numerical index.

\section{Measurement using Fuzzy Numbers}

As per Kahraman et al., [11], the opinion from humans is usually vague and subjective. Fuzzy set theory, introduced by Zadeh [12] may be used to manage the vagueness and subjectivity of human thoughts, particularly linguistic variables since it can represent vague expressions such as "usually," "fair" and "satisfied," which are regarded as the 
natural representation of respondents' preference and judgment. Bellman and Zadeh [13] were the first to relate fuzzy set theory to decision-making problems, as mentioned in Rao [14].

Rao [15] illustrated the conversion of the linguistic terms into triangular fuzzy numbers and then the fuzzy numbers into crisp scores using the method proposed by Chen and Hwang [16] on various scales such as 5 point, 7 point and 11 point scale. The reason of using triangular fuzzy numbers is its computational simplicity. In the present work, an 11point scale is used for representation of the qualitative attributes. Figure 1 show the linguistic terms to fuzzy numbers conversion. The crisp score of a fuzzy number ' $M$ ' is obtained as follows:qs

$\mu_{\max }(x)= \begin{cases}x, & 0 \leq x \leq 1 \\ 0, & \text { otherwise }\end{cases}$

$\mu_{\min }(x)= \begin{cases}1-x, & 0 \leq x \leq 1 \\ 0, & \text { otherwise }\end{cases}$

The fuzzy max and fuzzy min of fuzzy numbers are defined in a manner such that absolute locations of fuzzy numbers can be automatically incorporated in the comparison cases. The left score of each fuzzy number 'Mi' is defined as

$$
\mu_{L}\left(M_{i}\right)=\operatorname{Sup}_{X}\left[\mu_{\min }(x)^{\wedge} \mu_{M_{i}}(x)\right]
$$

The left score is a unique, crisp, real number in $(0,1)$. It is the maximum membership value of the intersection of fuzzy number Mi and the fuzzy min. The right score may be obtained in a similar manner:

$\mu_{R}\left(M_{i}\right)=\operatorname{Sup}_{X}\left[\mu_{\max }(x)^{\wedge} \mu_{M i}(x)\right]$

Again, right score is a crisp number $(0,1)$. Given the left and right scores, the total score of a fuzzy number Mi is defined as:

$\mu_{T}\left(M_{i}\right)=\left[\mu_{R}\left(M_{i}\right)+1-\mu_{L}\left(M_{i}\right)\right] / 2$ 


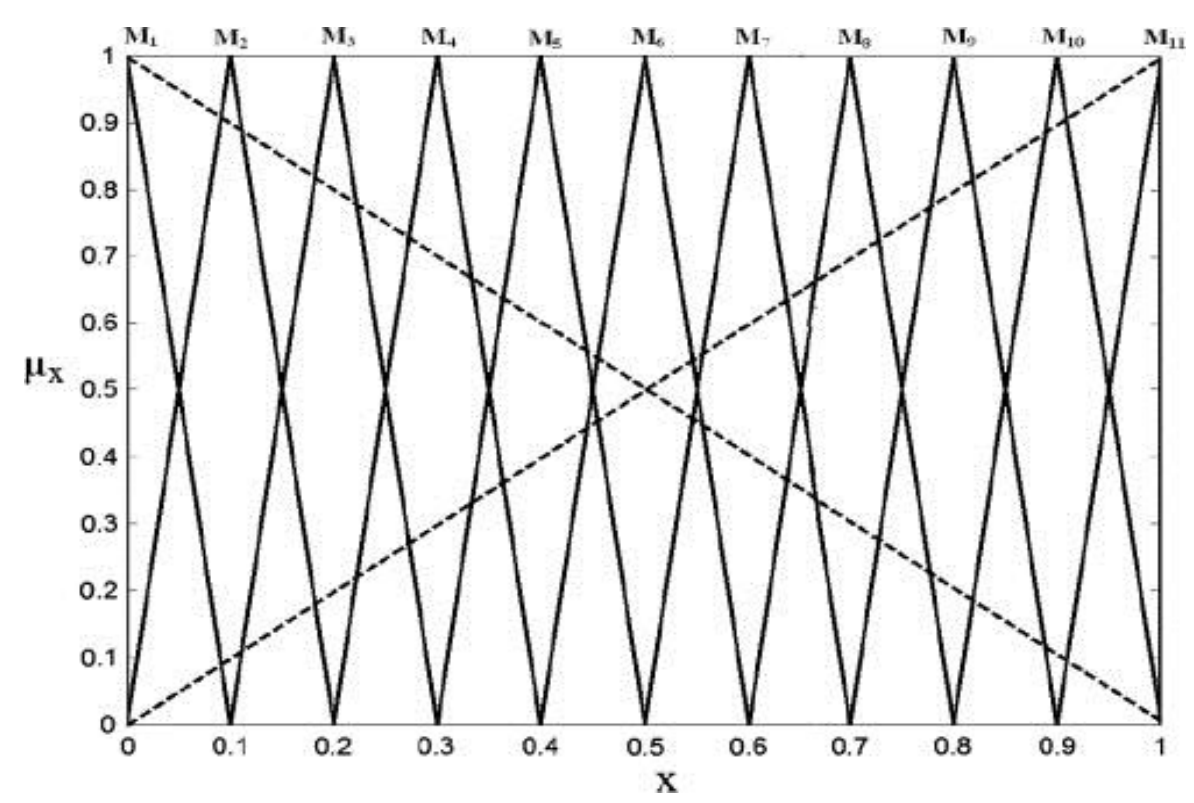

Figure 1. Linguistic Terms to Fuzzy Numbers Conversion (11-point scale) Source: Chen and Hwang [16]

By using the equations (1) to (5), the crisp score (total score) can be computed. Linguistic terms, Fuzzy Numbers and Crisp Scores for 11-point scale as calculated in Rao [15] are shown in Table 1.

Table 1. Conversion of Linguistic Terms into Crisp Scores (11-point scale)

\begin{tabular}{|l|l|l|l|}
\hline S.No. & Linguistic term & Fuzzy number & Crisp score \\
\hline 1 & Exceptionally low & M1 $(0,0,0.1)$ & 0.0455 \\
\hline 2 & Extremely low & M2(0,0.1,0.2) & 0.1364 \\
\hline 3 & Very low & M3(0.1,0.2,0..3) & 0.2273 \\
\hline 4 & Low & M4 $(0.2,0.3,0.4)$ & 0.3182 \\
\hline 5 & Below average & M5(0.3,0.4,0.5) & 0.4091 \\
\hline 6 & Average & M6(0.4,0.5,0.6) & 0.5000 \\
\hline 7 & Above average & M7(0.5,0.6,0.7) & 0.5909 \\
\hline 8 & High & M8(0.6,0.7,0.8) & 0.6818 \\
\hline 9 & Very high & M9(0.7,0.8,0.9) & 0.7727 \\
\hline 10 & Extremely high & $\mathrm{M} 10(0.8,0.9,1)$ & 0.8636 \\
\hline 11 & Exceptionally high & M11(0.9,1,1) & 0.9545 \\
\hline
\end{tabular}

Source: Rao [15]

The relative importance among the attributes can also be described using the same 11point scale as shown in Table 2. 


\section{Table 2. Conversion of Linguistic Terms into Fuzzy Scores (Relative Importance Value on an 11-point Scale)}

\begin{tabular}{|l|c|c|}
\hline \multicolumn{1}{|c|}{ Linguistic term } & Fuzzy number & $\begin{array}{c}\text { Crisp } \\
\text { score }\end{array}$ \\
\hline $\begin{array}{l}\text { One attribute is exceptionally less important than the } \\
\text { other }\end{array}$ & M1 & 0.0455 \\
\hline One attribute is extremely less important than the other & M2 & 0.1364 \\
\hline One attribute is very less important than the other & M3 & 0.2273 \\
\hline One attribute is less important than the other & M4 & 0.3182 \\
\hline One attribute is slightly less important than the other & M5 & 0.4091 \\
\hline Two attributes are equally important than the other & M6 & 0.5000 \\
\hline One attribute is slightly more important than the other & M7 & 0.5909 \\
\hline One attribute is more important than the other & M8 & 0.6818 \\
\hline One attribute is much more important than the other & M9 & 0.7727 \\
\hline One attribute is extremely more important than the other & M10 & 0.8636 \\
\hline $\begin{array}{l}\text { One attribute is exceptionally more important than the } \\
\text { other }\end{array}$ & M11 & 0.9545 \\
\hline
\end{tabular}

Source: Rao [15]

\section{Graph Theoretic Approach}

As explained in Gandhi and Agrawal [17], Graph theoretic approach (GTA) is a multidisciplinary systematic and logical approach to build and analyse systems. Graph theoretic and matrix model consists of digraph representation, matrix representation and permanent representation. GTA technique is used to calculate single numerical index for evaluation of critical attributes related to a problem. Some of the areas in which graph theory has been applied are mentioned in Table 3 .

\subsection{Digraph}

A digraph (directed graph) is used for representing the attributes (variables) under consideration and their interdependency within the system. A system digraph represents the attributes through its nodes and interdependency of the attributes is represented by the edges between the nodes. A node V $i$ represents the $i$ th attribute and the edges represents the relative importance between the attributes. The number of nodes in the digraph represents the total number of attributes considered for evaluation. In the digraph method, if a node ' $i$ ' exhibits relative importance over node ' $j$ ' during the evaluation, then a directed edge is drawn from node ' $i$ ' to node ' $j$ ' (i.e., Vij). But, If a node ' $j$ ' exhibits relative importance over node ' $i$ ' then a directed edge is drawn from node ' $j$ ' to node ' $i$ ' (i.e., Vji). Figure 2 shows a digraph having 6 attributes (vertices) connected through edges.

Table 3. A Few Areas in which Graph Theory has been Employed

\begin{tabular}{|c|l|l|}
\hline SNo & \multicolumn{1}{|c|}{ Paper Title } & \multicolumn{1}{c|}{ Author } \\
\hline 1 & 'FMEA - a digraph and matrix approach' & Gandhi and Agrawal [18] \\
\hline 2 & $\begin{array}{l}\text { Selection of automobile vehicle by evaluation } \\
\text { through graph theoretical methodology }\end{array}$ & $\begin{array}{l}\text { Venkatasamy and Agrawal } \\
{[19]}\end{array}$ \\
\hline 3 & $\begin{array}{l}\text { 'A digraph approach to TQM evaluation of an } \\
\text { industry' }\end{array}$ & Grover et al. [20] \\
\hline
\end{tabular}




\begin{tabular}{|c|l|l|}
\hline 4 & $\begin{array}{l}\text { Graph theory and matrix approach for } \\
\text { performance evaluation of TQM in Indian } \\
\text { industries }\end{array}$ & Kulkarni [21] \\
\hline 5 & $\begin{array}{l}\text { 'Human resource performance index in TQM } \\
\text { environment' }\end{array}$ & Grover et al. [22] \\
\hline 6 & $\begin{array}{l}\text { 'A material selection model using graph theory } \\
\text { and matrix approach' }\end{array}$ & Rao [23] \\
\hline 7 & $\begin{array}{l}\text { 'Selection of power plants by evaluation and } \\
\text { comparison using graph theoretical } \\
\text { methodology' }\end{array}$ & Garg et al. [24] \\
\hline 8 & $\begin{array}{l}\text { Selection, identification and comparison of } \\
\text { industrial robots using digraph and matrix } \\
\text { methods }\end{array}$ & Rao and Padmanabhan [25] \\
\hline 9 & $\begin{array}{l}\text { 'Quantification of risk mitigation environment } \\
\text { of supply chains using graph theory and matrix } \\
\text { methods' }\end{array}$ & Faisal et al. [26] \\
\hline 10 & $\begin{array}{l}\text { 'Graph models and mathematical programming } \\
\text { in biochemical network analysis and metabolic } \\
\text { engineering design' }\end{array}$ & Lanzeni et al. [27] \\
\hline 11 & $\begin{array}{l}\text { Critical factors of website performance: a graph } \\
\text { theoretic approach }\end{array}$ & Saha and Grover [28] \\
\hline 12 & $\begin{array}{l}\text { A fuzzy multi attribute decision making } \\
\text { approach for evaluating effectiveness of } \\
\text { advanced manufacturing technology - in Indian } \\
\text { context }\end{array}$ & Goyal and Grover [29] \\
\hline
\end{tabular}

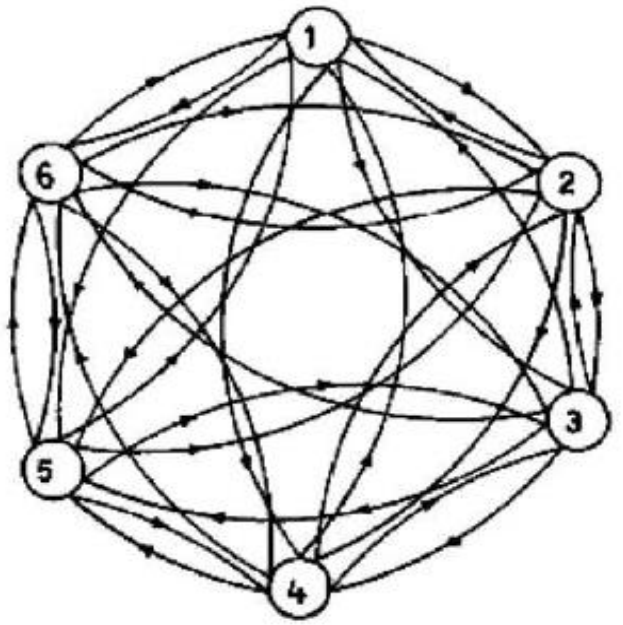

\section{Figure 2. Digraph Representing Six Attributes (vertices) and their Interdependency (Edges)}

For mathematical analysis, the digraph is represented in the matrix form. The matrix represents all the attributes and their interrelations. Matrix 1 is a $6 \times 6$ matrix and considers all the attributes $(\mathrm{D} i)$ and their relative importance $\left(i . e ., \mathrm{a}_{i j}\right)$ with respect to each other in the system. 


\section{Matrix 1. Matrix Representation of a Six Attributes Digraph}

\begin{tabular}{|c|c|c|c|c|c|c|}
\hline Attribute & 1 & 2 & 3 & 4 & 5 & 6 \\
\hline 1 & $\mathrm{D}_{1}$ & $a_{12}$ & $a_{13}$ & $a_{14}$ & $a_{15}$ & $\left.a_{16}\right)$ \\
\hline 2 & $a_{21}$ & $\mathrm{D}_{2}$ & $a_{23}$ & $a_{24}$ & $a_{25}$ & $a_{26}$ \\
\hline 3 & $a_{31}$ & $a_{32}$ & $\mathrm{D}_{3}$ & $a_{34}$ & $a_{35}$ & $a_{36}$ \\
\hline 4 & $a_{41}$ & $a_{42}$ & $a_{43}$ & $\mathrm{D}_{4}$ & $a_{45}$ & $a_{46}$ \\
\hline 5 & $a_{51}$ & $a_{52}$ & $a_{53}$ & $a_{54}$ & $\mathrm{D}_{5}$ & $a_{56}$ \\
\hline 6 & $a_{61}$ & $a_{62}$ & $a_{63}$ & $a_{64}$ & $a_{65}$ & $\mathrm{D}_{6}$ \\
\hline
\end{tabular}

In the matrix, ' $D i$ ' symbolizes the $i$ th evaluation attribute representing the node ' $V i$ '. $a_{i j}$ represents the relative importance among the attributes and is represented by the edge drawn from ' $i$ ' to ' $j$ ' in the digraph. The permanent function of the attribute matrix is represented as 'Per A'. Equation (6) shows the sigma form of the permanent function for six attributes. If the attributes are more, then it can be extended further.

$$
\text { per } \begin{aligned}
A= & \prod_{i=1}^{6} D_{i}+\sum_{i} \sum_{j} \sum_{k} \sum_{l} \sum_{m} \sum_{n}\left(a_{i j} a_{j i}\right) D_{k} D_{l} D_{m} D_{n} \\
& +\sum_{i} \sum_{j} \sum_{k} \sum_{l} \sum_{m} \sum_{n}\left(a_{i j} a_{j k} a_{k i}+a_{i k} a_{k j} a_{j i}\right) D_{l} D_{m} D_{n} \\
& +\left[\left(\underset{i}{\sum} \sum_{j} \sum_{k} \sum_{m} \sum_{m}\left(a_{i j} a_{j i}\right)\left(a_{k l} a_{l k}\right) D_{m} D_{n}\right.\right. \\
& \left.\left.+\sum_{i} \sum_{j} \sum_{k} \sum_{l} \sum_{m} \sum_{n}\left(a_{i j} a_{j k} a_{k l} a_{l i}+a_{i l} a_{l k} a_{k j} a_{j i}\right) D_{m} D_{n}\right)\right] \\
& +\left[\sum_{i} \sum_{j} \sum_{k} \sum_{l} \sum_{m} \sum_{n}\left(a_{i j} a_{j i}\right)\left(a_{k l} a_{l m} a_{m k}+a_{k m} a_{m l} a_{l k}\right) D_{n}\right. \\
& \left.+\sum_{i} \sum_{j} \sum_{k} \sum_{l} \sum_{m} \sum_{n}\left(a_{i j} a_{j k} a_{k l} a_{l m} a_{m i}+a_{i m} a_{m l} a_{l k} a_{k j} a_{j i}\right) D_{n}\right] \\
& +\left[\underset{i}{\sum} \sum_{j} \sum_{k} \sum_{l} \sum_{n}\left(a_{i j} a_{j i}\right)\left(a_{k l} a_{l m} a_{m n} a_{n k}+a_{k n} a_{n m} a_{m l} a_{l k}\right)\right. \\
& +\underset{i}{\sum} \sum_{j} \sum_{k} \sum_{l} \sum_{m} \sum_{n}\left(a_{i j} a_{j k} a_{k l}\right)\left(a_{l m} a_{m n} a_{n l}\right) \\
& +\underset{i}{\sum} \sum_{j} \sum_{k} \sum_{l} \sum_{m} \sum_{n}\left(a_{i j} a_{j i}\right)\left(a_{k l} a_{l k}\right)\left(a_{m n} a_{n m}\right) \\
& \left.+\underset{i}{\sum} \sum_{j} \sum_{k} \sum_{l} \sum_{m} \sum_{n}\left(a_{i j} a_{j k} a_{l m} a_{m n} a_{n i}+a_{i n} a_{n m} a_{m l} a_{l k} a_{k j} a_{j i}\right)\right]
\end{aligned}
$$

In equation (6), in total $(n+1)$ i.e., $(6+1)$ groups are made. These groups represent the measure of attributes and their relative importance. So, total seven groups are made, and their importance is discussed below.

The first group represents the measures of inheritance level of implementation factors. The second group is absent as there is no self-loop in the digraph. The third group contains interrelationships between the sub factors (i.e., $a_{i j} a_{j i}$ ) and measures of four remaining factors. The fourth group represents a set of three factors relative importance 
loop and measure of three factors. The fifth group contains two sub groups. The terms of the first subgroup represent the relative importance among the two factors and the measure of two implementation factors. The second subgroup contains the relative importance among the four factors and the measure of the two implementation factors. The sixth group contains two sub groups. The first sub-group is a set of two factor's interdependence, i.e., $a_{i j} a_{j i}$, a set of three factor interdependence, i.e., $a_{k l} a_{l m} a_{m k}$ or its pair $a_{k m} a_{m l} a_{l k}$ and measure of remaining implementation factor. The second sub-group is a set of five implementation factors interdependence, i.e., $a_{i j} a_{j k} a_{k l} a_{l m} a_{m i}$ or its pair $a_{i m} a_{m l} a_{l k} a_{k j} a_{j i}$ and measure of remaining implementation factor. Similarly, seventh group analyses subgrouping in terms of a set of two and four behavioural factor interdependence, 2 - three behavioural factor interdependence, 3 - two behavioural factor interdependence and six implementation factors interdependence.

\section{Methodology with Illustration of Fuzzy Graph Theoretic Approach}

Based on the study of Goyal and Grover [29], the methodology for computing TBSSB index using graph theory and fuzzy numbers can be summarised in the following steps

Step I: To identify and rank the various attributes (variables) that affect the service quality in TBSSB system.

Step II: To establish the relative importance of the attributes.

Step III: To develop a digraph of the attributes depending upon their interdependency.

Step IV: To develop a variable permanent function matrix on the basis of digraph.

Step V: To calculate the permanent function (index number) of the TBSSB system by using the values of the evaluation measures and their interdependency.

\section{Illustration}

The illustration of above methodology is given below

Step I: Identifying and ranking of the various attributes affecting the service quality in TBSSB system

The various attributes affecting TBSSB service quality are shown in Table 4 . The attributes are identified and adapted through a comprehensive review of various studies on automated service quality comprising of Joseph et al.,[2], Joseph and stone [30], Ibrahaim et al.,[5], Doll and Torkzadeh [31], Van Riel et al., [32], Yang et al., [33], Ganguli and Roy [8], Al-Hawari [34], Sahadev and Purani [35], Meuter et al., [36], Bauer et al., [37], Ho and Lin [38], Narteh [39], Sureshchandar et al., [40], Katono [41], Yen and Lu [42], Loonam and O'Loughlin [43], Coulter and Coulter [44], Bitner et al., [45], Ribbink et al., [46], Herington and Weaven [47], Kim and Lim [48], Chen and Hitt [49], Parasuraman et al., [50], Dabholkar and Bagozzi [51], Kumbhar [52], Dilijonas et al., [53] and Parasuraman [54].

A survey is conducted to find out the level of importance of TBSSB service quality attributes on 11-point scale ranging from exceptionally low to exceptionally high. The survey questionnaire constitutes many questions, but questions related only to the evaluation of attributes are used in this paper, and results have been shown. 
Table 4. List of Attributes

\begin{tabular}{|c|l|}
\hline Variable & \multicolumn{1}{|c|}{ Attribute } \\
\hline V1 & Security that customer personal information will not be shared with third party \\
\hline V2 & Guiding customers to solve problem, in case it occurs \\
\hline V3 & Conducting error free transaction every time \\
\hline V4 & Security in doing financial transaction \\
\hline V5 & Providing precise and sufficient information as per customer need \\
\hline V6 & Providing consistent services \\
\hline V7 & 24x7 service availability \\
\hline V8 & Giving prompt responses to customer request \\
\hline V9 & Ease of use \\
\hline V10 & Providing customer feedback services \\
\hline V11 & Giving directions to new users \\
\hline V12 & Having adequate menu options for everyday banking needs \\
\hline V13 & Acknowledging customer by name \\
\hline V14 & Having security features and customers awareness of the same \\
\hline V15 & Consuming less time as compared to branch banking \\
\hline V16 & Giving more freedom of mobility to customers \\
\hline V17 & Offering product according to customer preferences \\
\hline V18 & Having user friendly system \\
\hline
\end{tabular}

Data is collected using self-administered questionnaires from the customers of different banks in Delhi and NCR area in India using convenience sampling. The respondents who are above 18 years of age and use at least one mode of TBSSB services are only considered for the purpose of survey. Out of 600 distributed questionnaires, 440 are received back. Only 414 from 440 responses are usable, resulting in response rate of 69 percent. The value of Cronbach's alpha coefficient $(\alpha)$ is found to be 0.713 , indicating the reliability of the instrument. Table 5 presents the demographic profile of the respondents.

Mean values and ranking of the attributes are shown in Table 6. On the basis of table 1, different attributes are assigned crisp score corresponding to their ranking. Attribute V4 has the highest mean value of 10.39 , so highest rank 18 is assigned to V4. Therefore, highest crisp score of 0.9545 is assigned to V4, which represents exceptionally high attribute. Attribute V10 has the lowest mean value of 4.15, so lowest rank 1 is assigned to V10. Correspondingly, crisp score of 0.0455 is assigned to V10, which represents exceptionally low attribute. For other attributes in-between the highest and lowest rank, range is decided and attributes falling within a given range are assigned a particular crisp score as shown in Table 6.

Table 5. Profile of Respondents

\begin{tabular}{|c|c|c|}
\hline & & Percent \\
\hline \multirow[t]{2}{*}{ Gender } & Male & 57.00 \\
\hline & Female & 43.00 \\
\hline \multirow[t]{4}{*}{ Age } & 18- up to 25 yrs & 21.50 \\
\hline & More than 25 -up to 35 yrs & 38.40 \\
\hline & More than 35- up to 45 yrs & 30.00 \\
\hline & More than 45 yrs & 10.10 \\
\hline Highest Completed Education & 12th or Below & 2.20 \\
\hline
\end{tabular}




\begin{tabular}{|c|l|l|}
\hline \multirow{4}{*}{ Occupation } & Graduate & 66.40 \\
\cline { 2 - 3 } & Post Graduate and above & 31.40 \\
\hline \multirow{4}{*}{ Annual Income(in INR per annum) } & Student & 12.60 \\
\cline { 2 - 3 } & Salaried & 58.90 \\
\cline { 2 - 3 } & Self employed & 22.50 \\
\cline { 2 - 3 } & Others & 6.00 \\
\cline { 2 - 3 } & upto 2 Lacs & 21.00 \\
\cline { 2 - 3 } & More than 2- up to 5 Lacs & 39.60 \\
\cline { 2 - 3 } & More than 5- up to 10 Lacs & 30.20 \\
\hline \multirow{7}{*}{ TBSSB usage per month } & More than 10 Lacs & 3.20 \\
\hline & Up to 5 times & 31.83 \\
\cline { 2 - 3 } & More than 5 - up to 10 times & 10.63 \\
\cline { 2 - 3 } & More than 10 - up to 20 times & 3.14 \\
\cline { 2 - 3 } & More than 20 times & \\
\hline
\end{tabular}

Table 6. Mean Values, Rank and Crisp Score of Various Attributes

\begin{tabular}{|c|c|c|c|}
\hline Attribute & Mean Value & Rank & Crisp Score \\
\hline V4 & 10.39 & 18 & 0.9545 \\
\hline V3 & 9.85 & 17 & 0.8636 \\
\hline V9 & 9.75 & 16 & 0.8636 \\
\hline V7 & 9.20 & 15 & 0.7727 \\
\hline V15 & 8.88 & 14 & 0.6818 \\
\hline V1 & 8.58 & 13 & 0.6818 \\
\hline V2 & 8.51 & 12 & 0.6818 \\
\hline V14 & 7.89 & 11 & 0.5909 \\
\hline V6 & 7.75 & 10 & 0.5909 \\
\hline V18 & 7.67 & 9 & 0.5909 \\
\hline V12 & 7.47 & 8 & 0.5000 \\
\hline V8 & 7.32 & 7 & 0.5000 \\
\hline V11 & 7.24 & 6 & 0.5000 \\
\hline V5 & 6.61 & 5 & 0.4091 \\
\hline V17 & 6.16 & 4 & 0.3182 \\
\hline V16 & 5.25 & 3 & 0.2273 \\
\hline V13 & 4.65 & 2 & 0.1364 \\
\hline V10 & 4.15 & 1 & 0.0455 \\
\hline
\end{tabular}

Step II: Establishing the relative importance among the attributes

Relative importance of the attributes is established on the basis of their ranking Goyal and Grover [29]. To compare the two attributes, their corresponding mean values are subtracted. For example, to compare V1 with V2, their corresponding means $(8.58,8.51)$ are subtracted, which gives 0.07 (positive sign indicates that the first attribute is more important than the second one). 
Table 7. Pair Wise Difference of Mean between Attributes

\begin{tabular}{|c|c|c|c|c|c|c|c|c|c|c|c|c|c|c|c|c|c|c|}
\hline Var & V1 & V2 & v3 & V4 & V5 & V6 & V7 & v8 & V9 & V10 & V11 & V12 & V13 & V14 & V15 & V16 & V17 & V18 \\
\hline V1 & 0 & 0.07 & -1.27 & -1.81 & 1.97 & 0.83 & -0.62 & 1.26 & -1.17 & 4.43 & 1.34 & 1.11 & 3.93 & 0.69 & -0.30 & 3.33 & 2.42 & 0.91 \\
\hline V2 & -0.07 & 0 & -1.34 & -1.88 & 1.90 & 0.76 & -0.69 & 1.19 & -1.24 & 4.36 & 1.27 & 1.04 & 3.86 & 0.62 & -0.37 & 3.26 & 2.35 & 0.84 \\
\hline v3 & 1.27 & 1.34 & 0 & -0.54 & 3.24 & 2.10 & 0.65 & 2.53 & 0.10 & 5.70 & 2.61 & 2.38 & 5.20 & 1.96 & 0.97 & 4.60 & 3.69 & 2.18 \\
\hline V4 & 1.81 & 1.88 & 0.54 & 0 & 3.78 & 2.64 & 1.19 & 3.07 & 0.64 & 6.23 & 3.15 & 2.92 & 5.74 & 2.50 & 1.51 & 5.14 & 4.23 & 2.71 \\
\hline v5 & -1.97 & -1.90 & -3.24 & -3.78 & 0 & -1.14 & -2.59 & -0.71 & -3.14 & 2.46 & -0.63 & -0.86 & 1.96 & -1.28 & -2.27 & 1.36 & 0.45 & -1.06 \\
\hline V6 & -0.83 & -0.76 & -2.10 & -2.64 & 1.14 & 0 & -1.45 & 0.43 & -2.00 & 3.60 & 0.51 & 0.28 & 3.10 & -0.14 & -1.13 & 2.50 & 1.59 & 0.08 \\
\hline V7 & 0.62 & 0.69 & -0.65 & -1.19 & 2.59 & 1.45 & 0 & 1.88 & -0.55 & 5.05 & 1.96 & 1.73 & 4.55 & 1.31 & 0.32 & 3.95 & 3.04 & 1.53 \\
\hline v8 & -1.26 & -1.19 & -2.53 & -3.07 & 0.71 & -0.43 & -1.88 & 0 & -2.43 & 3.17 & 0.08 & -0.15 & 2.67 & -0.57 & -1.56 & 2.07 & 1.16 & -0.35 \\
\hline v9 & 1.17 & 1.24 & -0.10 & -0.64 & 3.14 & 2.00 & 0.55 & 2.43 & 0 & 5.60 & 2.51 & 2.28 & 5.10 & 1.86 & 0.87 & 4.50 & 3.59 & 2.08 \\
\hline V10 & -4.43 & -4.36 & -5.70 & -6.23 & -2.46 & -3.60 & -5.05 & -3.17 & -5.60 & 0 & -3.09 & -3.32 & -0.50 & -3.73 & -4.73 & -1.10 & -2.01 & -3.52 \\
\hline V11 & -1.34 & -1.27 & -2.61 & -3.15 & 0.63 & -0.51 & -1.96 & -0.08 & -2.51 & 3.09 & 0 & -0.23 & 2.59 & -0.65 & -1.64 & 1.99 & 1.08 & -0.43 \\
\hline V12 & -1.11 & -1.04 & -2.38 & -2.92 & 0.86 & -0.28 & -1.73 & 0.15 & -2.28 & 3.32 & 0.23 & o & 2.82 & -0.42 & -1.41 & 2.22 & 1.31 & -0.20 \\
\hline V13 & -3.93 & -3.86 & -5.20 & -5.74 & -1.96 & -3.10 & -4.55 & -2.67 & -5.10 & 0.50 & -2.59 & -2.82 & 0 & -3.24 & -4.23 & -0.60 & -1.51 & -3.02 \\
\hline V14 & -0.69 & -0.62 & -1.96 & -2.50 & 1.28 & 0.14 & -1.31 & 0.57 & -1.86 & 3.73 & 0.65 & 0.42 & 3.24 & 0 & -0.99 & 2.64 & 1.73 & 0.21 \\
\hline V15 & 0.30 & 0.37 & -0.97 & -1.51 & 2.27 & 1.13 & -0.32 & 1.56 & -0.87 & 4.73 & 1.64 & 1.41 & 4.23 & 0.99 & 0 & 3.63 & 2.72 & 1.21 \\
\hline V16 & -3.33 & -3.26 & -4.60 & -5.14 & -1.36 & -2.50 & -3.95 & -2.07 & -4.50 & 1.10 & -1.99 & -2.22 & 0.60 & -2.64 & -3.63 & 0 & -0.91 & -2.42 \\
\hline V17 & -2.42 & -2.35 & -3.69 & -4.23 & -0.45 & -1.59 & -3.04 & -1.16 & -3.59 & 2.01 & -1.08 & -1.31 & 1.51 & -1.73 & -2.72 & 0.91 & 0 & -1.51 \\
\hline V18 & -0.91 & -0.84 & -2.18 & -2.71 & 1.06 & -0.08 & -1.53 & 0.35 & -2.08 & 3.52 & 0.43 & 0.20 & 3.02 & -0.21 & -1.21 & 2.42 & 1.51 & 0 \\
\hline
\end{tabular}

Similarly, the difference of means is calculated for each pair as shown in Table 7. Difference of means gives the idea about, how much one attribute is important than the other. To assign the crisp score for each comparison, the mean differences are divided into 11 ranges on the 11-point scale and using the Table 2 crisp score is assigned to values falling in a particular range as shown in Table 8

Table 8. Mean Ranges on 11-point Scale (on the basis of Table 2)

\begin{tabular}{|c|c|c|c|}
\hline \multicolumn{1}{|c|}{ Linguistic terms } & $\begin{array}{c}\text { Fuzzy } \\
\text { Numbers }\end{array}$ & Mean Range & Crisp Score \\
\hline One attribute is exceptionally less important than the other & M1 & -5.83 to -7 & 0.0455 \\
\hline One attribute is extremely less important less than the other & M2 & -4.67 to -5.83 & 0.1364 \\
\hline One attribute is very less important than the other & M3 & -3.50 to -4.67 & 0.2273 \\
\hline One attribute is less important than the other & M4 & -2.34 to -3.50 & 0.3182 \\
\hline One attribute is slightly less important than the other & M5 & -1.17 to -2.34 & 0.4091 \\
\hline Two attribute are equally important than the other & M6 & -1.17 to 1.17 & 0.5000 \\
\hline One attribute is slightly more important than the other & M7 & 1.17 to 2.34 & 0.5909 \\
\hline One attribute is more important than the other & M8 & 2.34 to 3.50 & 0.6818 \\
\hline One attribute is much more important than the other & M9 & 3.50 to 4.67 & 0.7727 \\
\hline One attribute is extremely more important than the other & M10 & 4.67 to 5.83 & 0.8636 \\
\hline One attribute is exceptionally more important than the & M11 & 5.83 to 7 & 0.9545 \\
\hline
\end{tabular}

Each Pair wise difference of mean between attributes of Table 7 is converted into crisp score using Table 8 and is shown in Table 9. For example, the difference of means between V1 and V2 in table 7 is 0.07 , which is assigned crisp score 0.5000 as per Table 8. Similarly crisp values are assigned to other mean differences as per Table 8. 
Table 9. Relative Importance among Attributes in Terms of Crisp Score

\begin{tabular}{|c|c|c|c|c|c|c|c|c|c|c|c|c|c|c|c|c|c|c|}
\hline Var & V1 & V2 & V3 & V4 & V5 & V6 & V7 & v8 & V9 & V10 & V11 & V12 & V13 & V14 & V15 & V16 & V17 & V18 \\
\hline V1 & 0 & $\begin{array}{l}0.50 \\
00\end{array}$ & $\begin{array}{l}0.40 \\
91\end{array}$ & $\begin{array}{l}0.40 \\
91\end{array}$ & $\begin{array}{l}0.59 \\
09\end{array}$ & $\begin{array}{l}0.50 \\
00\end{array}$ & $\begin{array}{l}\text { 0.50 } \\
00\end{array}$ & $\begin{array}{l}0.59 \\
09\end{array}$ & $\begin{array}{l}0.40 \\
91\end{array}$ & $\begin{array}{l}0.77 \\
27\end{array}$ & $\begin{array}{l}0.59 \\
09\end{array}$ & $\begin{array}{l}\text { 0.50 } \\
00\end{array}$ & $\begin{array}{l}0.77 \\
27\end{array}$ & $\begin{array}{l}0.50 \\
00\end{array}$ & $\begin{array}{l}0.50 \\
00\end{array}$ & $\begin{array}{l}0.68 \\
18\end{array}$ & $\begin{array}{l}0.68 \\
18\end{array}$ & $\begin{array}{l}0.500 \\
0\end{array}$ \\
\hline V2 & $\begin{array}{l}0.50 \\
00\end{array}$ & 0 & $\begin{array}{l}0.40 \\
91\end{array}$ & $\begin{array}{l}0.40 \\
91\end{array}$ & $\begin{array}{l}0.59 \\
09\end{array}$ & $\begin{array}{l}0.50 \\
00\end{array}$ & $\begin{array}{l}0.50 \\
00\end{array}$ & $\begin{array}{l}0.59 \\
09\end{array}$ & $\begin{array}{l}0.40 \\
91\end{array}$ & $\begin{array}{l}0.77 \\
27\end{array}$ & $\begin{array}{l}0.59 \\
09\end{array}$ & $\begin{array}{l}0.50 \\
00\end{array}$ & $\begin{array}{l}0.77 \\
27\end{array}$ & $\begin{array}{l}0.50 \\
00\end{array}$ & $\begin{array}{l}0.50 \\
00\end{array}$ & $\begin{array}{l}0.68 \\
18\end{array}$ & $\begin{array}{l}0.68 \\
18\end{array}$ & $\begin{array}{l}0.500 \\
0\end{array}$ \\
\hline V3 & $\begin{array}{l}0.59 \\
09\end{array}$ & $\begin{array}{l}0.59 \\
09\end{array}$ & 0 & $\begin{array}{l}0.50 \\
00\end{array}$ & $\begin{array}{l}0.68 \\
18\end{array}$ & $\begin{array}{l}0.59 \\
09\end{array}$ & $\begin{array}{l}0.50 \\
00\end{array}$ & $\begin{array}{l}0.68 \\
18\end{array}$ & $\begin{array}{l}0.50 \\
00\end{array}$ & $\begin{array}{l}0.86 \\
36\end{array}$ & $\begin{array}{l}0.68 \\
18\end{array}$ & $\begin{array}{l}0.68 \\
18\end{array}$ & $\begin{array}{l}0.86 \\
36\end{array}$ & $\begin{array}{l}0.59 \\
09\end{array}$ & $\begin{array}{l}0.50 \\
00\end{array}$ & $\begin{array}{l}0.77 \\
27\end{array}$ & $\begin{array}{l}0.77 \\
27\end{array}$ & $\begin{array}{l}0.590 \\
9\end{array}$ \\
\hline V4 & $\begin{array}{l}0.59 \\
09\end{array}$ & $\begin{array}{l}0.59 \\
09\end{array}$ & $\begin{array}{l}0.50 \\
00\end{array}$ & 0 & $\begin{array}{l}\mathbf{0 . 7 7} \\
27\end{array}$ & $\begin{array}{l}0.68 \\
18\end{array}$ & $\begin{array}{l}\mathbf{0 . 5 9} \\
09\end{array}$ & $\begin{array}{l}0.68 \\
18\end{array}$ & $\begin{array}{l}0.50 \\
00\end{array}$ & $\begin{array}{l}0.95 \\
45\end{array}$ & $\begin{array}{l}0.68 \\
18\end{array}$ & $\begin{array}{l}0.68 \\
18\end{array}$ & $\begin{array}{l}0.86 \\
36\end{array}$ & $\begin{array}{l}0.68 \\
18\end{array}$ & $\begin{array}{l}0.59 \\
09\end{array}$ & $\begin{array}{l}0.86 \\
36\end{array}$ & $\begin{array}{l}\mathbf{0 . 7 7} \\
27\end{array}$ & $\begin{array}{l}0.681 \\
8\end{array}$ \\
\hline V5 & $\begin{array}{l}0.40 \\
91\end{array}$ & $\begin{array}{l}0.40 \\
91\end{array}$ & $\begin{array}{l}0.31 \\
82\end{array}$ & $\begin{array}{l}0.22 \\
73\end{array}$ & 0 & $\begin{array}{l}0.50 \\
00\end{array}$ & $\begin{array}{l}0.31 \\
82\end{array}$ & $\begin{array}{l}0.50 \\
00\end{array}$ & $\begin{array}{l}0.31 \\
82\end{array}$ & $\begin{array}{l}0.68 \\
18\end{array}$ & $\begin{array}{l}0.50 \\
00\end{array}$ & $\begin{array}{l}0.50 \\
00\end{array}$ & $\begin{array}{l}0.59 \\
09\end{array}$ & $\begin{array}{l}0.40 \\
91\end{array}$ & $\begin{array}{l}0.40 \\
91\end{array}$ & $\begin{array}{l}0.59 \\
09\end{array}$ & $\begin{array}{l}\text { 0.50 } \\
00\end{array}$ & $\begin{array}{l}0.500 \\
0\end{array}$ \\
\hline V6 & $\begin{array}{l}0.50 \\
00\end{array}$ & $\begin{array}{l}0.50 \\
00\end{array}$ & $\begin{array}{l}0.40 \\
91\end{array}$ & $\begin{array}{l}0.31 \\
82\end{array}$ & $\begin{array}{l}0.50 \\
00\end{array}$ & 0 & $\begin{array}{l}0.40 \\
91\end{array}$ & $\begin{array}{l}0.50 \\
00\end{array}$ & $\begin{array}{l}0.40 \\
91\end{array}$ & $\begin{array}{l}0.77 \\
27\end{array}$ & $\begin{array}{l}0.50 \\
00\end{array}$ & $\begin{array}{l}0.50 \\
00\end{array}$ & $\begin{array}{l}0.68 \\
18\end{array}$ & $\begin{array}{l}0.50 \\
00\end{array}$ & $\begin{array}{l}0.50 \\
00\end{array}$ & $\begin{array}{l}0.68 \\
18\end{array}$ & $\begin{array}{l}0.59 \\
09\end{array}$ & $\begin{array}{l}0.500 \\
0\end{array}$ \\
\hline V7 & $\begin{array}{l}0.50 \\
00\end{array}$ & $\begin{array}{l}0.50 \\
00\end{array}$ & $\begin{array}{l}0.50 \\
00\end{array}$ & $\begin{array}{l}0.40 \\
91\end{array}$ & $\begin{array}{l}0.68 \\
18\end{array}$ & $\begin{array}{l}0.59 \\
09\end{array}$ & 0 & $\begin{array}{l}0.59 \\
09\end{array}$ & $\begin{array}{l}0.50 \\
00\end{array}$ & $\begin{array}{l}0.86 \\
36\end{array}$ & $\begin{array}{l}0.59 \\
09\end{array}$ & $\begin{array}{l}0.59 \\
09\end{array}$ & $\begin{array}{l}0.77 \\
27\end{array}$ & $\begin{array}{l}0.59 \\
09\end{array}$ & $\begin{array}{l}0.50 \\
00\end{array}$ & $\begin{array}{l}0.77 \\
27\end{array}$ & $\begin{array}{l}0.68 \\
18\end{array}$ & $\begin{array}{l}0.590 \\
9\end{array}$ \\
\hline v8 & $\begin{array}{l}0.40 \\
91\end{array}$ & $\begin{array}{l}0.40 \\
91\end{array}$ & $\begin{array}{l}0.31 \\
82\end{array}$ & $\begin{array}{l}0.31 \\
82\end{array}$ & $\begin{array}{l}\mathbf{0 . 5 0} \\
00\end{array}$ & $\begin{array}{l}0.50 \\
00\end{array}$ & $\begin{array}{l}0.40 \\
91\end{array}$ & 0 & $\begin{array}{l}0.31 \\
82\end{array}$ & $\begin{array}{l}0.68 \\
18\end{array}$ & $\begin{array}{l}0.50 \\
00\end{array}$ & $\begin{array}{l}\mathbf{0 . 5 0} \\
00\end{array}$ & $\begin{array}{l}0.68 \\
18\end{array}$ & $\begin{array}{l}0.50 \\
00\end{array}$ & $\begin{array}{l}0.40 \\
91\end{array}$ & $\begin{array}{l}0.59 \\
09\end{array}$ & $\begin{array}{l}0.59 \\
09\end{array}$ & $\begin{array}{l}0.500 \\
0\end{array}$ \\
\hline V9 & $\begin{array}{l}0.59 \\
09\end{array}$ & $\begin{array}{l}0.59 \\
09\end{array}$ & $\begin{array}{l}0.50 \\
00\end{array}$ & $\begin{array}{l}0.50 \\
00\end{array}$ & $\begin{array}{l}0.68 \\
18\end{array}$ & $\begin{array}{l}0.59 \\
09\end{array}$ & $\begin{array}{l}\mathbf{0 . 5 0} \\
00\end{array}$ & $\begin{array}{l}0.68 \\
18\end{array}$ & 0 & $\begin{array}{l}0.86 \\
36\end{array}$ & $\begin{array}{l}0.68 \\
18\end{array}$ & $\begin{array}{l}0.59 \\
09\end{array}$ & $\begin{array}{l}0.86 \\
36\end{array}$ & $\begin{array}{l}0.59 \\
09\end{array}$ & $\begin{array}{l}0.50 \\
00\end{array}$ & $\begin{array}{l}0.77 \\
27\end{array}$ & $\begin{array}{l}0.77 \\
27\end{array}$ & $\begin{array}{l}0.590 \\
9\end{array}$ \\
\hline V10 & $\begin{array}{l}0.22 \\
73\end{array}$ & $\begin{array}{l}0.22 \\
73\end{array}$ & $\begin{array}{l}0.13 \\
64\end{array}$ & $\begin{array}{l}0.04 \\
55\end{array}$ & $\begin{array}{l}0.31 \\
82\end{array}$ & $\begin{array}{l}0.22 \\
73\end{array}$ & $\begin{array}{l}0.13 \\
64\end{array}$ & $\begin{array}{l}0.31 \\
82\end{array}$ & $\begin{array}{l}0.13 \\
64\end{array}$ & 0 & $\begin{array}{l}0.31 \\
82\end{array}$ & $\begin{array}{l}0.31 \\
82\end{array}$ & $\begin{array}{l}0.50 \\
00\end{array}$ & $\begin{array}{l}0.22 \\
73\end{array}$ & $\begin{array}{l}0.13 \\
64\end{array}$ & $\begin{array}{l}0.50 \\
00\end{array}$ & $\begin{array}{l}0.40 \\
91\end{array}$ & $\begin{array}{l}0.227 \\
3\end{array}$ \\
\hline V11 & $\begin{array}{l}0.40 \\
91\end{array}$ & $\begin{array}{l}0.40 \\
91\end{array}$ & $\begin{array}{l}0.31 \\
82\end{array}$ & $\begin{array}{l}0.31 \\
82\end{array}$ & $\begin{array}{l}\mathbf{0 . 5 0} \\
00\end{array}$ & $\begin{array}{l}0.50 \\
00\end{array}$ & $\begin{array}{l}0.40 \\
91\end{array}$ & $\begin{array}{l}0.50 \\
00\end{array}$ & $\begin{array}{l}0.31 \\
82\end{array}$ & $\begin{array}{l}0.68 \\
18\end{array}$ & 0 & $\begin{array}{l}\mathbf{0 . 5 0} \\
00\end{array}$ & $\begin{array}{l}0.68 \\
18\end{array}$ & $\begin{array}{l}0.50 \\
00\end{array}$ & $\begin{array}{l}0.40 \\
91\end{array}$ & $\begin{array}{l}0.59 \\
09\end{array}$ & $\begin{array}{l}0.50 \\
00\end{array}$ & $\begin{array}{l}0.500 \\
0\end{array}$ \\
\hline V12 & $\begin{array}{l}0.50 \\
00\end{array}$ & $\begin{array}{l}0.50 \\
00\end{array}$ & $\begin{array}{l}0.31 \\
82\end{array}$ & $\begin{array}{l}0.31 \\
82\end{array}$ & $\begin{array}{l}\mathbf{0 . 5 0} \\
\mathbf{0 0}\end{array}$ & $\begin{array}{l}0.50 \\
00\end{array}$ & $\begin{array}{l}0.40 \\
91\end{array}$ & $\begin{array}{l}0.50 \\
00\end{array}$ & $\begin{array}{l}0.40 \\
91\end{array}$ & $\begin{array}{l}0.68 \\
18\end{array}$ & $\begin{array}{l}0.50 \\
00\end{array}$ & 0 & $\begin{array}{l}0.68 \\
18\end{array}$ & $\begin{array}{l}0.50 \\
00\end{array}$ & $\begin{array}{l}0.40 \\
91\end{array}$ & $\begin{array}{l}0.59 \\
09\end{array}$ & $\begin{array}{l}0.59 \\
09\end{array}$ & $\begin{array}{l}0.500 \\
0\end{array}$ \\
\hline V13 & $\begin{array}{l}0.22 \\
73\end{array}$ & $\begin{array}{l}0.22 \\
73\end{array}$ & $\begin{array}{l}0.13 \\
64\end{array}$ & $\begin{array}{l}0.13 \\
64\end{array}$ & $\begin{array}{l}0.40 \\
91\end{array}$ & $\begin{array}{l}0.31 \\
82\end{array}$ & $\begin{array}{l}0.22 \\
73\end{array}$ & $\begin{array}{l}0.31 \\
82\end{array}$ & $\begin{array}{l}0.13 \\
64\end{array}$ & $\begin{array}{l}0.50 \\
00\end{array}$ & $\begin{array}{l}0.31 \\
82\end{array}$ & $\begin{array}{l}0.31 \\
82\end{array}$ & 0 & $\begin{array}{l}0.31 \\
82\end{array}$ & $\begin{array}{l}0.22 \\
73\end{array}$ & $\begin{array}{l}0.50 \\
00\end{array}$ & $\begin{array}{l}0.40 \\
91\end{array}$ & $\begin{array}{l}0.318 \\
2\end{array}$ \\
\hline V14 & $\begin{array}{l}0.50 \\
00\end{array}$ & $\begin{array}{l}0.50 \\
00\end{array}$ & $\begin{array}{l}0.40 \\
91\end{array}$ & $\begin{array}{l}0.31 \\
82\end{array}$ & $\begin{array}{l}0.59 \\
09\end{array}$ & $\begin{array}{l}0.50 \\
00\end{array}$ & $\begin{array}{l}0.40 \\
91\end{array}$ & $\begin{array}{l}0.50 \\
00\end{array}$ & $\begin{array}{l}0.40 \\
91\end{array}$ & $\begin{array}{l}0.77 \\
27\end{array}$ & $\begin{array}{l}0.50 \\
00\end{array}$ & $\begin{array}{l}\mathbf{0 . 5 0} \\
00\end{array}$ & $\begin{array}{l}0.68 \\
18\end{array}$ & $\mathbf{0}$ & $\begin{array}{l}0.50 \\
00\end{array}$ & $\begin{array}{l}0.68 \\
18\end{array}$ & $\begin{array}{l}0.59 \\
09\end{array}$ & $\begin{array}{l}0.500 \\
0\end{array}$ \\
\hline V15 & $\begin{array}{l}0.50 \\
00\end{array}$ & $\begin{array}{l}0.50 \\
00\end{array}$ & $\begin{array}{l}0.50 \\
00\end{array}$ & $\begin{array}{l}0.40 \\
91\end{array}$ & $\begin{array}{l}0.59 \\
09\end{array}$ & $\begin{array}{l}0.50 \\
00\end{array}$ & $\begin{array}{l}\mathbf{0 . 5 0} \\
\mathbf{0 0}\end{array}$ & $\begin{array}{l}0.59 \\
09\end{array}$ & $\begin{array}{l}0.50 \\
00\end{array}$ & $\begin{array}{l}0.86 \\
36\end{array}$ & $\begin{array}{l}0.59 \\
09\end{array}$ & $\begin{array}{l}0.59 \\
09\end{array}$ & $\begin{array}{l}0.77 \\
27\end{array}$ & $\begin{array}{l}0.50 \\
00\end{array}$ & 0 & $\begin{array}{l}0.77 \\
27\end{array}$ & $\begin{array}{l}0.68 \\
18\end{array}$ & $\begin{array}{l}0.590 \\
9\end{array}$ \\
\hline V16 & $\begin{array}{l}0.31 \\
82\end{array}$ & $\begin{array}{l}0.31 \\
82\end{array}$ & $\begin{array}{l}0.22 \\
73\end{array}$ & $\begin{array}{l}0.13 \\
64\end{array}$ & $\begin{array}{l}0.40 \\
91\end{array}$ & $\begin{array}{l}0.31 \\
82\end{array}$ & $\begin{array}{l}0.22 \\
73\end{array}$ & $\begin{array}{l}0.40 \\
91\end{array}$ & $\begin{array}{l}0.22 \\
73\end{array}$ & $\begin{array}{l}0.50 \\
00\end{array}$ & $\begin{array}{l}0.40 \\
91\end{array}$ & $\begin{array}{l}0.40 \\
91\end{array}$ & $\begin{array}{l}0.50 \\
00\end{array}$ & $\begin{array}{l}0.31 \\
82\end{array}$ & $\begin{array}{l}0.22 \\
73\end{array}$ & 0 & $\begin{array}{l}0.50 \\
00\end{array}$ & $\begin{array}{l}0.318 \\
2\end{array}$ \\
\hline V17 & $\begin{array}{l}0.31 \\
82\end{array}$ & $\begin{array}{l}0.31 \\
82\end{array}$ & $\begin{array}{l}0.22 \\
73\end{array}$ & $\begin{array}{l}0.22 \\
73\end{array}$ & $\begin{array}{l}\mathbf{0 . 5 0} \\
00\end{array}$ & $\begin{array}{l}0.40 \\
91\end{array}$ & $\begin{array}{l}0.31 \\
82\end{array}$ & $\begin{array}{l}0.50 \\
00\end{array}$ & $\begin{array}{l}0.22 \\
73\end{array}$ & $\begin{array}{l}0.59 \\
09\end{array}$ & $\begin{array}{l}0.50 \\
00\end{array}$ & $\begin{array}{l}0.40 \\
91\end{array}$ & $\begin{array}{l}0.59 \\
09\end{array}$ & $\begin{array}{l}0.40 \\
91\end{array}$ & $\begin{array}{l}0.31 \\
82\end{array}$ & $\begin{array}{l}0.50 \\
00\end{array}$ & 0 & $\begin{array}{l}0.409 \\
1\end{array}$ \\
\hline V18 & $\begin{array}{l}0.50 \\
00\end{array}$ & $\begin{array}{l}0.50 \\
00\end{array}$ & $\begin{array}{l}0.40 \\
91\end{array}$ & $\begin{array}{l}0.31 \\
82\end{array}$ & $\begin{array}{l}0.50 \\
00\end{array}$ & $\begin{array}{l}0.50 \\
00\end{array}$ & $\begin{array}{l}0.40 \\
91\end{array}$ & $\begin{array}{l}0.50 \\
00\end{array}$ & $\begin{array}{l}0.40 \\
91\end{array}$ & $\begin{array}{l}0.77 \\
27\end{array}$ & $\begin{array}{l}0.50 \\
00\end{array}$ & $\begin{array}{l}0.50 \\
00\end{array}$ & $\begin{array}{l}0.68 \\
18\end{array}$ & $\begin{array}{l}0.50 \\
00\end{array}$ & $\begin{array}{l}0.40 \\
91\end{array}$ & $\begin{array}{l}0.68 \\
18\end{array}$ & $\begin{array}{l}0.59 \\
09\end{array}$ & 0 \\
\hline
\end{tabular}

Step III: Developing a digraph of the attributes depending upon their interdependency

The Digraph for evaluation of attributes is presented in Figure 3. A TBSSB service quality digraph represents 18 attributes in the form of 18 nodes from V1 to V18. The edges between the nodes represent the interdependency of the attributes. 


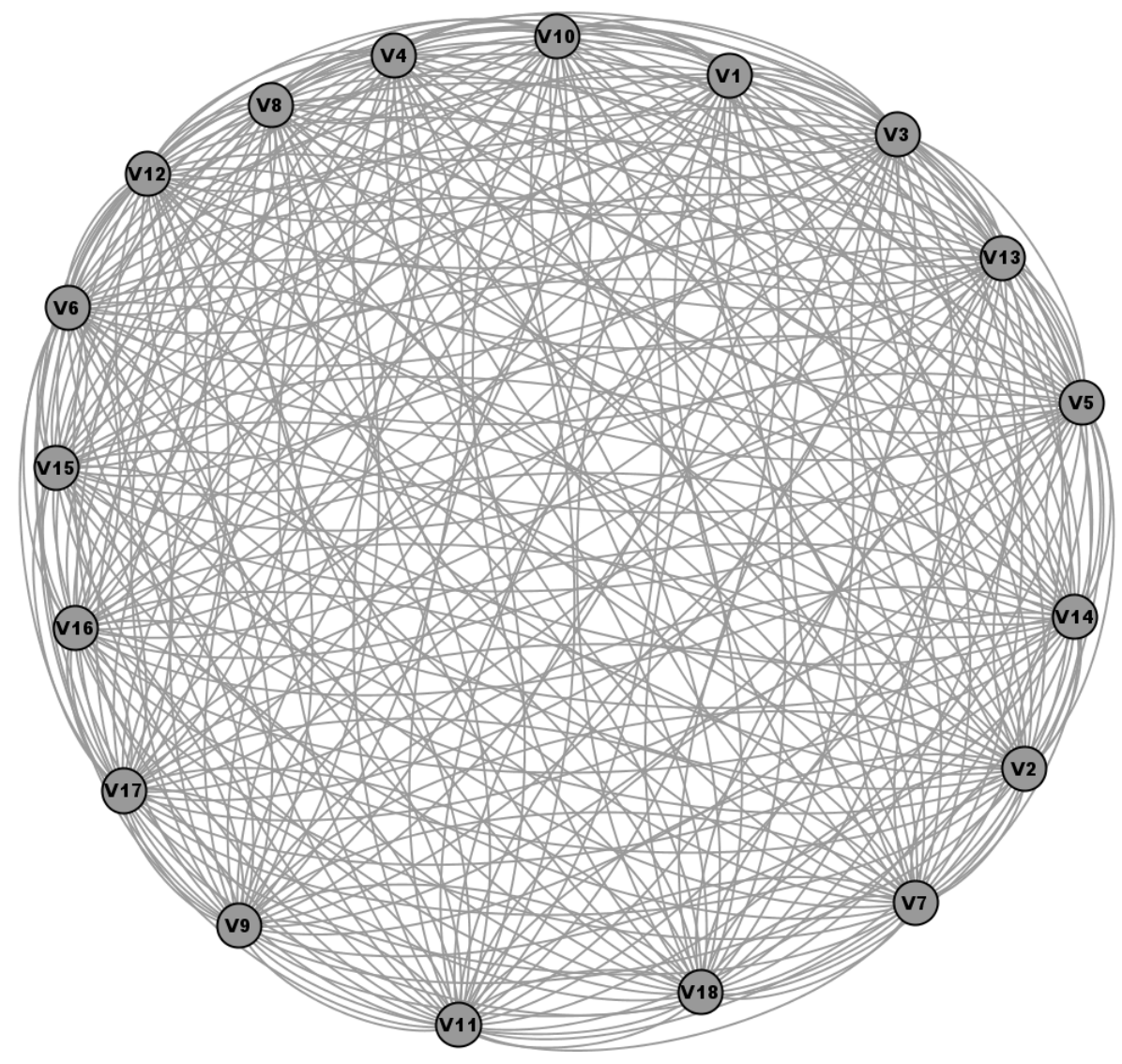

Figure 3. Digraph for Attributes Evaluation of TBSSB System

Step IV: Developing an attribute permanent function matrix on the basis of digraph.

An 18X18 matrix with diagonal elements representing the attributes and non-diagonal elements representing the relative importance among the attributes is prepared for calculating the permanent of a matrix. In the matrix, the off diagonal elements represent the relative importance values as shown in Table 9. The crisp scores of attributes (Table 6) are used as diagonal element values for the purpose of calculation of permanent function of the matrix. The resultant matrix is shown in matrix 2 .

Matrix 2. Matrix for Computing Permanent Function of TBSSB

\begin{tabular}{|c|c|c|c|c|c|c|c|c|c|c|c|c|c|c|c|c|c|c|}
\hline Var & V1 & V2 & V3 & V4 & V5 & V6 & V7 & v8 & V9 & V10 & V11 & V12 & V13 & V14 & V15 & V16 & V17 & V18 \\
\hline V1 & $\begin{array}{l}0.68 \\
18\end{array}$ & $\begin{array}{l}0.50 \\
00\end{array}$ & $\begin{array}{l}0.40 \\
91\end{array}$ & $\begin{array}{l}0.40 \\
91\end{array}$ & $\begin{array}{l}0.59 \\
09\end{array}$ & $\begin{array}{l}0.50 \\
00\end{array}$ & $\begin{array}{l}0.50 \\
00\end{array}$ & $\begin{array}{l}0.59 \\
09\end{array}$ & $\begin{array}{l}0.4 \\
091\end{array}$ & $\begin{array}{l}0.7 \\
727\end{array}$ & $\begin{array}{l}0.5 \\
909\end{array}$ & $\begin{array}{l}0.5 \\
000\end{array}$ & $\begin{array}{l}0.7 \\
727\end{array}$ & $\begin{array}{l}0.5 \\
000\end{array}$ & $\begin{array}{l}0.5 \\
000\end{array}$ & $\begin{array}{l}0.6 \\
818\end{array}$ & $\begin{array}{l}0.6 \\
818\end{array}$ & 0.5000 \\
\hline V2 & $\begin{array}{l}0.50 \\
00 \\
\end{array}$ & $\begin{array}{l}0.68 \\
18 \\
\end{array}$ & $\begin{array}{l}0.40 \\
91 \\
\end{array}$ & $\begin{array}{l}0.40 \\
91 \\
\end{array}$ & $\begin{array}{l}0.59 \\
09\end{array}$ & $\begin{array}{l}0.50 \\
00 \\
\end{array}$ & $\begin{array}{l}0.50 \\
00 \\
\end{array}$ & $\begin{array}{l}0.59 \\
09 \\
\end{array}$ & $\begin{array}{l}0.4 \\
091 \\
\end{array}$ & $\begin{array}{l}0.7 \\
727 \\
\end{array}$ & $\begin{array}{l}0.5 \\
909 \\
\end{array}$ & $\begin{array}{l}0.5 \\
000 \\
\end{array}$ & $\begin{array}{l}0.7 \\
727 \\
\end{array}$ & $\begin{array}{l}0.5 \\
000 \\
\end{array}$ & $\begin{array}{l}0.5 \\
000 \\
\end{array}$ & $\begin{array}{l}0.6 \\
818 \\
\end{array}$ & $\begin{array}{l}0.6 \\
818 \\
\end{array}$ & 0.5000 \\
\hline $\mathbf{V 3}$ & $\begin{array}{l}0.59 \\
09\end{array}$ & $\begin{array}{l}0.59 \\
09\end{array}$ & $\begin{array}{l}0.86 \\
36\end{array}$ & $\begin{array}{l}0.50 \\
00\end{array}$ & $\begin{array}{l}.68 \\
18\end{array}$ & $\begin{array}{l}0.59 \\
09\end{array}$ & $\begin{array}{l}0.50 \\
00\end{array}$ & $\begin{array}{l}0.68 \\
18\end{array}$ & $\begin{array}{l}0.5 \\
000\end{array}$ & $\begin{array}{l}0.8 \\
636\end{array}$ & $\begin{array}{l}0.6 \\
818\end{array}$ & $\begin{array}{l}0.6 \\
818\end{array}$ & $\begin{array}{l}0.8 \\
636\end{array}$ & $\begin{array}{c}0.5 \\
909\end{array}$ & $\begin{array}{l}0.5 \\
000\end{array}$ & $\begin{array}{l}0.7 \\
727\end{array}$ & $\begin{array}{l}0.7 \\
727\end{array}$ & 0.5909 \\
\hline V4 & $\begin{array}{l}0.59 \\
09\end{array}$ & $\begin{array}{l}.59 \\
09\end{array}$ & $\begin{array}{l}\mathbf{0 . 5 0} \\
\mathbf{0 0}\end{array}$ & $\begin{array}{l}0.95 \\
45\end{array}$ & $\begin{array}{l}0.77 \\
27\end{array}$ & $\begin{array}{l}0.68 \\
18\end{array}$ & $\begin{array}{l}.59 \\
09\end{array}$ & $\begin{array}{l}0.68 \\
18\end{array}$ & $\begin{array}{l}0.5 \\
000\end{array}$ & $\begin{array}{l}0.9 \\
545\end{array}$ & $\begin{array}{l}0.6 \\
818\end{array}$ & $\begin{array}{l}0.6 \\
818\end{array}$ & $\begin{array}{l}0.8 \\
636\end{array}$ & $\begin{array}{l}0.6 \\
818\end{array}$ & $\begin{array}{l}0.5 \\
909\end{array}$ & $\begin{array}{l}0.8 \\
636\end{array}$ & $\begin{array}{l}0.7 \\
727\end{array}$ & 0.6818 \\
\hline V5 & $\begin{array}{l}0.40 \\
91 \\
\end{array}$ & $\begin{array}{l}0.40 \\
91 \\
\end{array}$ & $\begin{array}{l}0.31 \\
82 \\
\end{array}$ & $\begin{array}{l}0.22 \\
73 \\
\end{array}$ & $\begin{array}{l}0.40 \\
91 \\
\end{array}$ & $\begin{array}{l}0.50 \\
00 \\
\end{array}$ & $\begin{array}{l}0.31 \\
82 \\
\end{array}$ & $\begin{array}{l}0.50 \\
00 \\
\end{array}$ & $\begin{array}{l}0.3 \\
182 \\
\end{array}$ & $\begin{array}{l}0.6 \\
818 \\
\end{array}$ & $\begin{array}{l}0.5 \\
000 \\
\end{array}$ & $\begin{array}{l}0.5 \\
000 \\
\end{array}$ & $\begin{array}{l}0.5 \\
909 \\
\end{array}$ & $\begin{array}{l}0.4 \\
091 \\
\end{array}$ & $\begin{array}{l}0.4 \\
091 \\
\end{array}$ & $\begin{array}{l}0.5 \\
909 \\
\end{array}$ & $\begin{array}{l}0.5 \\
000 \\
\end{array}$ & 0.5000 \\
\hline V6 & $\begin{array}{l}0.50 \\
00\end{array}$ & $\begin{array}{l}0.50 \\
00\end{array}$ & $\begin{array}{l}0.40 \\
91\end{array}$ & $\begin{array}{l}0.31 \\
82\end{array}$ & $\begin{array}{l}0.50 \\
00\end{array}$ & $\begin{array}{l}0.59 \\
09\end{array}$ & $\begin{array}{l}0.40 \\
91\end{array}$ & $\begin{array}{l}0.50 \\
00\end{array}$ & $\begin{array}{l}0.4 \\
091\end{array}$ & $\begin{array}{l}0.7 \\
727\end{array}$ & $\begin{array}{l}0.5 \\
000\end{array}$ & $\begin{array}{l}0.5 \\
000\end{array}$ & $\begin{array}{l}0.6 \\
818\end{array}$ & $\begin{array}{l}0.5 \\
000\end{array}$ & $\begin{array}{l}0.5 \\
000\end{array}$ & $\begin{array}{l}0.6 \\
818\end{array}$ & $\begin{array}{l}0.5 \\
909\end{array}$ & 0.5000 \\
\hline V7 & $\begin{array}{l}0.50 \\
00\end{array}$ & $\begin{array}{l}0.50 \\
00\end{array}$ & $\begin{array}{l}0.50 \\
00\end{array}$ & $\begin{array}{l}0.40 \\
91\end{array}$ & $\begin{array}{l}.68 \\
18\end{array}$ & $\begin{array}{l}0.59 \\
09\end{array}$ & $\begin{array}{l}0.77 \\
27\end{array}$ & \begin{tabular}{|l|}
0.59 \\
09
\end{tabular} & $\begin{array}{l}0.5 \\
000\end{array}$ & $\begin{array}{l}0.8 \\
636\end{array}$ & $\begin{array}{l}0.5 \\
909\end{array}$ & $\begin{array}{l}0.5 \\
909\end{array}$ & $\begin{array}{l}0.7 \\
727\end{array}$ & $\begin{array}{l}0.5 \\
909\end{array}$ & $\begin{array}{l}0.5 \\
000\end{array}$ & $\begin{array}{l}0.7 \\
727\end{array}$ & $\begin{array}{l}0.6 \\
818\end{array}$ & 0.5909 \\
\hline V8 & $\begin{array}{l}0.40 \\
91\end{array}$ & $\begin{array}{l}0.40 \\
91\end{array}$ & $\begin{array}{l}0.31 \\
82\end{array}$ & $\begin{array}{l}0.31 \\
82\end{array}$ & $\begin{array}{l}0.50 \\
00\end{array}$ & $\begin{array}{l}0.50 \\
00\end{array}$ & $\begin{array}{l}0.40 \\
91\end{array}$ & $\begin{array}{l}\mathbf{0 . 5 0} \\
\mathbf{0 0}\end{array}$ & $\begin{array}{l}0.3 \\
182\end{array}$ & $\begin{array}{l}0.6 \\
818\end{array}$ & $\begin{array}{l}0.5 \\
000\end{array}$ & $\begin{array}{l}0.5 \\
000\end{array}$ & $\begin{array}{l}0.6 \\
818\end{array}$ & $\begin{array}{l}0.5 \\
000\end{array}$ & $\begin{array}{l}0.4 \\
091\end{array}$ & $\begin{array}{l}0.5 \\
909\end{array}$ & $\begin{array}{l}0.5 \\
909\end{array}$ & 0.5000 \\
\hline V9 & $\begin{array}{l}0.59 \\
09\end{array}$ & $\begin{array}{l}0.59 \\
09\end{array}$ & $\begin{array}{l}0.50 \\
00\end{array}$ & $\begin{array}{l}0.50 \\
00\end{array}$ & $\begin{array}{l}0.68 \\
18\end{array}$ & $\begin{array}{l}0.59 \\
09\end{array}$ & $\begin{array}{l}.50 \\
00\end{array}$ & $\begin{array}{l}0.68 \\
18\end{array}$ & $\begin{array}{l}0.8 \\
636\end{array}$ & $\begin{array}{l}0.8 \\
636\end{array}$ & $\begin{array}{l}0.6 \\
818\end{array}$ & $\begin{array}{l}0.5 \\
909\end{array}$ & $\begin{array}{l}0.8 \\
636\end{array}$ & $\begin{array}{l}0.5 \\
909\end{array}$ & $\begin{array}{l}0.5 \\
000\end{array}$ & $\begin{array}{l}0.7 \\
727\end{array}$ & $\begin{array}{l}0.7 \\
727\end{array}$ & 0.5909 \\
\hline
\end{tabular}




\begin{tabular}{|c|c|c|c|c|c|c|c|c|c|c|c|c|c|c|c|c|c|c|}
\hline V10 & $\begin{array}{l}0.22 \\
73 \\
\end{array}$ & $\begin{array}{l}0.22 \\
73 \\
\end{array}$ & $\begin{array}{l}0.13 \\
64 \\
\end{array}$ & $\begin{array}{l}0.04 \\
55 \\
\end{array}$ & $\begin{array}{l}0.31 \\
82\end{array}$ & $\begin{array}{l}0.22 \\
73 \\
\end{array}$ & $\begin{array}{l}0.13 \\
64 \\
\end{array}$ & $\begin{array}{l}0.31 \\
82\end{array}$ & $\begin{array}{l}0.1 \\
364 \\
\end{array}$ & $\begin{array}{l}0.0 \\
455\end{array}$ & $\begin{array}{l}0.3 \\
182 \\
\end{array}$ & $\begin{array}{l}0.3 \\
182 \\
\end{array}$ & $\begin{array}{l}0.5 \\
000\end{array}$ & $\begin{array}{l}0.2 \\
273 \\
\end{array}$ & $\begin{array}{l}0.1 \\
364 \\
\end{array}$ & $\begin{array}{l}0.5 \\
000\end{array}$ & $\begin{array}{l}0.4 \\
091 \\
\end{array}$ & 0.2273 \\
\hline V11 & $\begin{array}{l}0.40 \\
91\end{array}$ & $\begin{array}{l}0.40 \\
91\end{array}$ & $\begin{array}{l}0.31 \\
82\end{array}$ & $\begin{array}{l}0.31 \\
82\end{array}$ & $\begin{array}{l}\mathbf{0 . 5 0} \\
00\end{array}$ & $\begin{array}{l}\text { 0.50 } \\
00\end{array}$ & $\begin{array}{l}0.40 \\
91\end{array}$ & $\begin{array}{l}.50 \\
00\end{array}$ & $\begin{array}{l}0.3 \\
182\end{array}$ & $\begin{array}{l}0.6 \\
818\end{array}$ & $\begin{array}{l}0.5 \\
000\end{array}$ & $\begin{array}{l}0.5 \\
000\end{array}$ & $\begin{array}{l}0.6 \\
818\end{array}$ & $\begin{array}{l}0.5 \\
000\end{array}$ & $\begin{array}{l}0.4 \\
091\end{array}$ & $\begin{array}{l}0.5 \\
909\end{array}$ & $\begin{array}{l}0.5 \\
000\end{array}$ & 0.5000 \\
\hline V12 & $\begin{array}{l}0.50 \\
00\end{array}$ & $\begin{array}{l}0.50 \\
00\end{array}$ & $\begin{array}{l}0.31 \\
82\end{array}$ & $\begin{array}{l}0.31 \\
82\end{array}$ & $\begin{array}{l}0.50 \\
00\end{array}$ & $\begin{array}{l}0.50 \\
00\end{array}$ & $\begin{array}{l}0.40 \\
91\end{array}$ & $\begin{array}{l}0.50 \\
00\end{array}$ & $\begin{array}{l}0.4 \\
091\end{array}$ & $\begin{array}{l}0.6 \\
818\end{array}$ & $\begin{array}{l}0.5 \\
000\end{array}$ & $\begin{array}{l}0.5 \\
000\end{array}$ & $\begin{array}{l}0.6 \\
818\end{array}$ & $\begin{array}{l}0.5 \\
000\end{array}$ & $\begin{array}{l}0.4 \\
091\end{array}$ & $\begin{array}{l}0.5 \\
909\end{array}$ & $\begin{array}{l}0.5 \\
909\end{array}$ & 0.5000 \\
\hline V13 & $\begin{array}{l}0.22 \\
73 \\
\end{array}$ & $\begin{array}{l}0.22 \\
73\end{array}$ & $\begin{array}{l}0.13 \\
64 \\
\end{array}$ & $\begin{array}{l}0.13 \\
64\end{array}$ & $\begin{array}{l}0.40 \\
91\end{array}$ & $\begin{array}{l}0.31 \\
82\end{array}$ & $\begin{array}{l}0.22 \\
73 \\
\end{array}$ & $\begin{array}{l}0.31 \\
82\end{array}$ & $\begin{array}{l}0.1 \\
364 \\
\end{array}$ & $\begin{array}{l}0.5 \\
000\end{array}$ & $\begin{array}{l}0.3 \\
182\end{array}$ & $\begin{array}{l}0.3 \\
182 \\
\end{array}$ & $\begin{array}{l}0.1 \\
364 \\
\end{array}$ & $\begin{array}{l}0.3 \\
182 \\
\end{array}$ & $\begin{array}{l}0.2 \\
273\end{array}$ & $\begin{array}{l}0.5 \\
000\end{array}$ & $\begin{array}{l}0.4 \\
091 \\
\end{array}$ & 0.3182 \\
\hline V14 & $\begin{array}{l}\text { 0.50 } \\
00\end{array}$ & $\begin{array}{l}0.50 \\
00\end{array}$ & $\begin{array}{l}0.40 \\
91\end{array}$ & $\begin{array}{l}0.31 \\
82\end{array}$ & $\begin{array}{l}0.59 \\
09\end{array}$ & $\begin{array}{l}\text { 0.50 } \\
00\end{array}$ & $\begin{array}{l}0.40 \\
91\end{array}$ & $\begin{array}{l}.50 \\
00\end{array}$ & $\begin{array}{l}0.4 \\
091\end{array}$ & $\begin{array}{l}0.7 \\
727\end{array}$ & $\begin{array}{l}0.5 \\
000\end{array}$ & $\begin{array}{l}0.5 \\
000\end{array}$ & $\begin{array}{l}0.6 \\
818\end{array}$ & $\begin{array}{l}0.5 \\
909\end{array}$ & $\begin{array}{l}0.5 \\
000\end{array}$ & $\begin{array}{l}0.6 \\
818\end{array}$ & $\begin{array}{l}0.5 \\
909\end{array}$ & 0.5000 \\
\hline V15 & $\begin{array}{l}0.50 \\
00\end{array}$ & $\begin{array}{l}0.50 \\
00\end{array}$ & $\begin{array}{l}0.50 \\
00\end{array}$ & $\begin{array}{l}0.40 \\
91\end{array}$ & $\begin{array}{l}.59 \\
09\end{array}$ & $\begin{array}{l}0.50 \\
00\end{array}$ & $\begin{array}{l}0.50 \\
00\end{array}$ & $\begin{array}{l}0.59 \\
09\end{array}$ & $\begin{array}{l}0.5 \\
000\end{array}$ & $\begin{array}{l}0.8 \\
636\end{array}$ & $\begin{array}{l}0.5 \\
909\end{array}$ & $\begin{array}{l}0.5 \\
909\end{array}$ & $\begin{array}{l}0.7 \\
727\end{array}$ & $\begin{array}{l}0.5 \\
000\end{array}$ & $\begin{array}{l}0.6 \\
818\end{array}$ & $\begin{array}{l}0.7 \\
727\end{array}$ & $\begin{array}{l}0.6 \\
818\end{array}$ & 0.5909 \\
\hline V16 & $\begin{array}{l}0.31 \\
82\end{array}$ & $\begin{array}{l}0.31 \\
82\end{array}$ & $\begin{array}{l}.22 \\
73\end{array}$ & $\begin{array}{l}0.13 \\
64\end{array}$ & $\begin{array}{l}0.40 \\
91\end{array}$ & $\begin{array}{l}0.31 \\
82\end{array}$ & $\begin{array}{l}0.22 \\
73\end{array}$ & $\begin{array}{l}0.40 \\
91\end{array}$ & $\begin{array}{l}0.2 \\
273 \\
\end{array}$ & $\begin{array}{l}0.5 \\
000\end{array}$ & $\begin{array}{l}0.4 \\
091\end{array}$ & $\begin{array}{l}0.4 \\
091\end{array}$ & $\begin{array}{l}0.5 \\
000\end{array}$ & $\begin{array}{l}0.3 \\
182\end{array}$ & $\begin{array}{l}0.2 \\
273\end{array}$ & $\begin{array}{l}0.2 \\
273\end{array}$ & $\begin{array}{l}0.5 \\
000\end{array}$ & 0.3182 \\
\hline V17 & $\begin{array}{l}0.31 \\
82\end{array}$ & $\begin{array}{l}0.31 \\
82\end{array}$ & $\begin{array}{l}0.22 \\
73\end{array}$ & $\begin{array}{l}0.22 \\
73\end{array}$ & $\begin{array}{l}0.50 \\
00\end{array}$ & $\begin{array}{l}0.40 \\
91\end{array}$ & $\begin{array}{l}0.31 \\
82\end{array}$ & $\begin{array}{l}0.50 \\
00\end{array}$ & $\begin{array}{l}0.2 \\
273\end{array}$ & $\begin{array}{l}0.5 \\
909\end{array}$ & $\begin{array}{l}0.5 \\
000\end{array}$ & $\begin{array}{l}0.4 \\
091\end{array}$ & $\begin{array}{l}0.5 \\
909\end{array}$ & $\begin{array}{l}0.4 \\
091\end{array}$ & $\begin{array}{l}0.3 \\
182\end{array}$ & $\begin{array}{l}0.5 \\
000\end{array}$ & $\begin{array}{l}0.3 \\
182\end{array}$ & 0.4091 \\
\hline V18 & $\begin{array}{l}0.50 \\
00\end{array}$ & $\begin{array}{l}0.50 \\
00\end{array}$ & $\begin{array}{l}0.40 \\
91\end{array}$ & $\begin{array}{l}0.31 \\
82\end{array}$ & $\begin{array}{l}0.50 \\
00\end{array}$ & $\begin{array}{l}\text { 0.50 } \\
00\end{array}$ & $\begin{array}{l}0.40 \\
91\end{array}$ & $\begin{array}{l}\text { 0.50 } \\
00\end{array}$ & $\begin{array}{l}0.4 \\
091\end{array}$ & $\begin{array}{l}0.7 \\
727\end{array}$ & $\begin{array}{l}0.5 \\
000\end{array}$ & $\begin{array}{l}0.5 \\
000\end{array}$ & $\begin{array}{l}0.6 \\
818\end{array}$ & $\begin{array}{l}0.5 \\
000\end{array}$ & $\begin{array}{l}0.4 \\
091\end{array}$ & $\begin{array}{l}0.6 \\
818\end{array}$ & $\begin{array}{l}0.5 \\
909\end{array}$ & 0.5909 \\
\hline
\end{tabular}

Step V: Calculation of permanent function

The TBSSB service quality permanent function is represented as:

TBSSB service quality permanent function $=\operatorname{Per}(T B S S B)$

The expanded form of the above equation in terms of various groups and sub-groups can be made in the same manner as that of equation 6.

Per (TBSSB) or TBSSB index is calculated by considering the data from Matrix 2. Permanent function value is calculated with the help of computer program (wxMaxima version 13.04.2). The calculated value is

$$
\text { Per }(\text { TBSSB })=10181961183 \text { (i.e., } 1.0181961183 \times 10^{10} \text { ) }
$$

TBSSB index is maximum when the performance effect of all the attributes is maximum. For obtaining Per $\left(\mathrm{TBSSB}_{\mathrm{Max}}\right)$, the diagonal elements of the Matrix 2 are replaced by 0.9545 (highest crisp value) and off diagonal elements are kept same. The calculated value of maximum permanent function of TBSSB matrix is

$$
\text { Per }\left(\text { TBSSB }_{\text {Max }}\right)=24579293935 \text { (i.e., } 2.4579293935 \times 10^{10} \text { ) }
$$

Similarly, Minimum TBSSB index is calculated by replacing diagonal elements of Matrix 2 with 0.0455 (lowest crisp value). The calculated value of minimum permanent function of TBSSB matrix is

$$
\operatorname{Per}\left(\mathrm{TBSSB}_{\mathrm{Min}}\right)=3565249961 \text { (i.e., } 3.565249961 \times 10^{9} \text { ) }
$$

The maximum and minimum value of TBSSB index indicates the range with in which it may vary. Banks may conduct a survey and find TBSSB index for their organisation.

\section{Conclusions and Implications}

In this paper, attempt is made to quantify the overall effect of TBSSB service quality. In total 18 attributes affecting TBSSB service quality are considered for the purpose of evaluation. Fuzzy numbers and Graph Theoretic Approach (GTA) is used to compute single numerical index for the TBSSB service quality system using a five step sequential process. Firstly, various attributes affecting service quality of TBSSB system are identified and ranked by conducting a survey. Reliability of the questionnaire is tested using Cronbach's alpha test. After that the relative importance among the attributes is established. The survey data is converted into crisp score by using 11-point scale. Then a digraph is made on the basis of the interdependency between the attributes. Using the digraph, an attribute permanent function matrix is developed. Finally, using the values of the evaluation measures and their interdependency, index number for the TBSSB system 
is calculated. Calculations are also made for maximum and minimum value of TBSSB index.

The banking sector which keeps on experimenting with new technologies can adopt this methodology to evaluate their technology. Banks may conduct the survey and find TBSSB quality index for their respective organisations. Banks may assess themselves by comparing their automated service quality index with maximum and minimum computed value of TBSSB. At a particular period of time, similar banks may be compared and rated by computing TBSSB indices. Index value can be computed for different modes of automated banking and values may be used for the purpose of inter banking mode comparison. Index may also be calculated for branch banking service quality. By calculating this index, banks will be in a position to compare their automated banking quality with that of branch banking. By doing this, they may justify their investments in technology based services. In short, this will helps bank managers to make decisions related to various aspects of automated banking including future investments which ultimately will result in better quality, higher customer satisfaction, loyalty and profitability. The methodology used in this paper can be extended to any number of attributes. This study may act as a reference towards future research work. The same GTA approach using fuzzy numbers for computing index value may be replicated for other services like telecommunications, online retailing and insurance.

\section{References}

[1] A. J. Joshua, "Adoption of Technology Enabled Banking Self Services: antecedents and consequences", $\mathrm{PhD}$ thesis, Cochin University of Science and Technology, Kochi, India, (2009).

[2] M. Joseph, C. McClure and B. Joseph, "Service quality in the banking sector: the impact of technology on service delivery", International Journal of Bank Marketing, vol. 17, no. 4, (1999), pp. 182-91.

[3] A. J. Broderick and S. Vachirapornpuk, "Service quality in internet banking: the importance of customer role”, Marketing Intelligence \& Planning, vol. 20, no. 6, (2002), pp. 327-335.

[4] M. Al-Hawari, N. Hartley and T. Ward, "Measuring banks' automated service quality: a confirmatory factor analysis approach", Marketing Bulletin, vol. 16, no. 1, (2005), pp. 1-19.

[5] E. E. Ibrahim, M. Joseph and K. I. Ibeh, "Customers' perception of electronic service delivery in the UK retail banking sector", International Journal of Bank Marketing, vol. 24, no. 7, (2006), pp. 475-493.

[6] E. Rasolinezhad, "Evaluating electronic banking systems in developing nations through Analytic Hierarchy Process model: a case study", International Journal of Electronic Finance, vol. 3, no. 4, (2009), pp. 325-338.

[7] A. P. Amiri, M. P. Amiri and M. P. Amiri, "Improving the Effective Factors on E-banking System by using Fuzzy TOPSIS in Parsian Bank", Journal of Applied Sciences, vol. 9, no. 15, (2009).

[8] S. Ganguli and S. K. Roy, "Generic technology based service quality dimensions in banking: Impact on customer satisfaction and loyalty", International Journal of Bank Marketing, vol. 29, no. 2, (2011), pp. 168-189.

[9] C. Kahraman and T. Kaya, "A fuzzy approach to e-banking website quality assessment based on an integrated AHP-ELECTRE method", Technological and Economic Development of Economy, no. 2, (2011), pp. 313-334.

[10] R. Elbadrawy, A. F. A. Moneim and M. N. Fors, "A Hybrid Model AHP and PROMETHEE for Evaluation of E-Banking Services", Proceedings of the 2014 Industrial and Systems Engineering Research conference, Montréal, Canada, (2014) May 31-June 3.

[11] C. Kahraman, N. Y. Ates and S. Cevik, "Hierarchical fuzzy TOPSIS model for selection among logistics information technologies", Journal of Enterprise Information Management, vol. 20, no. 2, (2007), pp. 143-68.

[12] L. A. Zadeh, "Fuzzy set", Information and Control, vol. 8, no. 3, (1965), pp. 338-53.

[13] R. E. Bellman and L. E. Zadeh, "Decision-making in a fuzzy environment", Management Science, Rao, R. V. (2007) Decision making in the manufacturing environment: using graph theory and fuzzy multiple attribute decision making method, Springer, UK, vol. 17, no. 4, (1970), pp. 212-223.

[14] R. V. Rao, "Decision making in the manufacturing environment: using graph theory and fuzzy multiple attribute decision making methods", Springer Science \& Business Media, (2007).

[15] R. V. Rao, "Decision Making in Manufacturing Environment Using Graph Theory and Fuzzy Multiple Attribute Decision Making Methods", Springer, UK, (2013).

[16] S. J. Chen and C. L. Hwang, "Fuzzy Multiple Attribute Decision Making Methods and Applications", Springer, New York, (1992).

[17] O. P. Gandhi and V. P. Agrawal, "Failure cause analysis - a structural approach", Journal of Pressure Vessel Technology, vol. 118, no. 4, (1996), pp. 434-439. 
[18] O. P. Gandhi and V. P. Agrawal, "FMEA - a digraph and matrix approach", Reliability Engineering and System Safety, vol. 35, no. 2, (1992), pp. 147-158.

[19] R. Venkatasamy and V. P. Agrawal, "Selection of automobile vehicle by evaluation through graph theoretical methodology", International journal of vehicle design, vol. 17, no. 4, (1996), pp. 449-470.

[20] S. Grover, V. P. Agrawal and I. A. Khan, "A digraph approach to TQM evaluation of an industry", International Journal of Production Research, vol. 42, no. 19, (2004), pp. 4031-4053.

[21] S. Kulkarni, "Graph theory and matrix approach for performance evaluation of TQM in Indian industries", The TQM magazine, vol. 17, no. 6, (2005), pp. 509-526.

[22] S. Grover, V. P. Agrawal and I. A. Khan, "Role of human factors in TQM: a graph theoretic approach", International Journal of Benchmarkig, vol. 13, no. 4, (2006), pp. 447-468.

[23] R. V. Rao, "A material selection model using graph theory and matrix approach", Materials Science and Engineering, vol. 431, no. 1-2, (2006), pp. 248-255.

[24] R. K. Garg, V. P. Agrawal and V. K. Gupta, "Selection of power plants by evaluation and comparison using graph theoretical methodology", Electrical Power and Energy Systems, vol. 28, no. 6, (2006), pp. 429-435.

[25] R. V. Rao and K. K. Padmanabhan, "Selection, identification and comparison of industrial robots using digraph and matrix methods", Robotics and Computer-Integrated Manufacturing, vol. 22, no. 4, (2006), pp. 373-383.

[26] M. N. Faisal, D. K. Banwet and R. Shankar, "Quantification of risk mitigation environment of supply chains using graph theory and matrix methods", European Journal of Industrial Engineering, vol. 1, no. 1, (2007), pp. 22-39.

[27] S .Lanzeni, E. Messina and F. Archetti, "Graph models and mathematical programming in biochemical network analysis and metabolic engineering design", Computers and Mathematics with Applications, vol. 55, no. 5, (2008), pp. 970-983.

[28] R. Saha and S. Grover, "Critical factors of website performance: a graph theoretic approach", International Journal of Web Science, vol. 1, no. 1, (2011), pp. 54-98.

[29] S. Goyal and S. Grover, "A fuzzy multi attribute decision making approach for evaluating effectiveness of advanced manufacturing technology-in Indian context", International Journal of Productivity and Quality Management, vol. 11, no. 2, (2013), pp. 150-178.

[30] M. Joseph and G. Stone, "An empirical evaluation of US bank customer perceptions of the impact of technology on service delivery in the banking sector", International Journal of Retail \& Distribution Management, vol. 31, no. 4, (2003), pp. 190-202.

[31] W. J. Doll and G. Torkzadeh, "The measurement of end-user computing satisfaction", MIS Quarterly, vol. 12, no. 2, (1988), pp. 259-74.

[32] A. C. R. Van Riel, V. Liljander and P. Jurriens, "Exploring consumer evaluations of e-services: a portal site”, International Journal of Service Industry Management, vol. 12, no. 4, (2001), pp. 359-77.

[33] Z. Yang, M. Joon and R. T. Peterson, "Measuring customer perceived online service quality: scale development and managerial implications", International Journal of Operations \& Production Management, vol. 24, no. 11, (2004), pp. 1149-74.

[34] M. A. Al-Hawari, "Automated service quality as a predictor of customers' commitment: a practical study within the UAE retail banking context", Asia Pacific Journal of Marketing and Logistics, vol. 23, no. 3, (2011), pp. 346-366.

[35] S. Sahadev and K. Purani, "Modelling the consequences of e-service quality", Marketing Intelligence \& Planning, vol. 26, no. 6, (2008), pp. 605-620.

[36] M. L. Meuter, A. L. Ostrom, R. I. Roundtree and M. J. Bitner, "Self-service technologies: understanding customer satisfaction with technology-based service encounters", Journal of Marketing, vol. 64, no. 3, (2000), pp. 50-64.

[37] H. H. Bauer, M. Hammerschmidt and T. Falk, "Measuring the quality of e-banking portals", International Journal of Bank Marketing, vol. 23, no. 2, (2005), pp. 153-75.

[38] C. B. Ho and W. Lin, "Measuring service quality of internet banking: scale development and validation", European Business Review, vol. 22, no. 1, (2010), pp. 5-24.

[39] B. Narteh, "Service quality in automated teller machines: an empirical investigation", Managing Service Quality, vol. 23, no. 1, (2013), pp. 62-89.

[40] G. Sureshchandar, C. Rajendran and R. N. Anantharaman, "Determinants of customer perceived service quality: A confirmatory factor analysis approach", Journal of Services Marketing, vol. 16, no 1, (2002), pp. 9-34.

[41] I. W. Katono, "Construction of an instrument to measure social valuation in an emerging market context", Education and Training, vol. 53, no. 5, (2011), pp. 371-86.

[42] C. Yen and H. Lu, "Effects of e-service quality on loyalty intention: an empirical study in online auction", Managing Service Quality, vol. 18, no. 2, (2008), pp. 127-46.

[43] M. Loonam and D. O'Loughlin, "Exploring e-service quality: a study of Irish online banking", Marketing Intelligence \& Planning, vol. 26, no. 7, (2008), pp. 759-80.

[44] K. Coulter and R. Coulter, "Determinants of trust in service providers: the moderating role of length of relationship", Journal of Services Marketing, vol. 16, no. 1, (2002), pp. 35-50. 
[45] M. J. Bitner, S. W. Brown and M. L. Meuter, "Technology infusion in service encounters", Journal of the Academy of Marketing Science, vol. 28, no. 1, (2000), pp. 138-49.

[46] D. Ribbink, A. Riel, V. Liljander and S. Streukens, "Comfort your online customer: quality, trust, and loyalty on the internet", Managing Service Quality, vol. 14, no. 6, (2004), pp. 446-456.

[47] C. Herington and S. Weaven, "Can banks improve customer relationships with high quality online services?", Managing Service Quality, vol. 17, no. 4, (2007), pp. 404-427.

[48] S. Y. Kim and Y. J. Lim, "Consumers' perceived importance of and satisfaction with internet shopping", Electronic Markets, vol. 11, no. 3, (2001), pp. 148-54.

[49] P. Y. Chen and L. M. Hitt, "Measuring switching costs and the determinants of customer retention in internet-enabled businesses: a study of the online brokerage industry", Information Systems Research, vol. 13, no. 3, (2002), pp. 255-274.

[50] A. Parasuraman, V. A. Zeithaml and A. Malhotra, "E-S-QUAL: a multiple-item scale for assessing electronic service quality", Journal of Service Research, vol. 7, no. 3, (2005), pp. 213-233.

[51] P. Dabholkar and R. P. Bagozzi, "An attitudinal model of technology-based self-service: moderating effects of consumer traits and situational factors", Journal of the Academy of Marketing Science, vol. 30, no. 3, (2002), pp. 184-201.

[52] V. M. Kumbhar, "Reliability and validity of 'eBankQual' scale in ATM Service Setting: a study", Vinimaya, vol. 31, no. 4, (2011), pp. 15-26.

[53] D. Dilijonas, D. Kriksciunien, V. Sakalauskas and R. Simutis, "Sustainability based service quality approach for automated teller machine network", Proceedings of the 5th International Vilnius Conference (KORSD-2009), Vilnius, Lithuania, (2009) September 30-October 3.

[54] A. Parasuraman, "Technology readiness index (TRI): a multiple-item scale to measure readiness to embrace new technologies”, Journal of Service Research, vol. 2, no. 4, (2000), pp. 307-320.

\section{Authors}

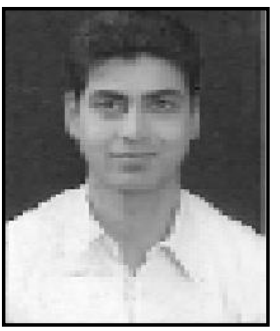

Rajiv Sindwani, is working as an assistant professor at YMCA University of Science and Technology, Faridabad, India. He is having total 9 years of experience in various sectors including consumer durables, banking and education. Currently, he is doing research in the area of service quality in technology based self service banking. He has published papers in national and international journals.

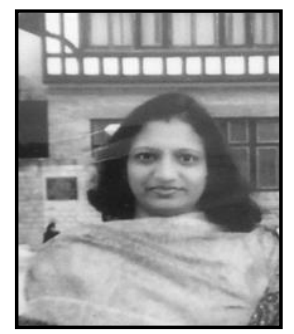

Dr Manisha Goel, holds a $\mathrm{PhD}$ degree. She has authored many papers in national and international journals. With more than 13 years of teaching and research experience, currently she is working as Associate Professor at the YMCA University of Science and Technology, Faridabad, India. 
International Journal of Advanced Science and Technology Vol.80 (2015) 